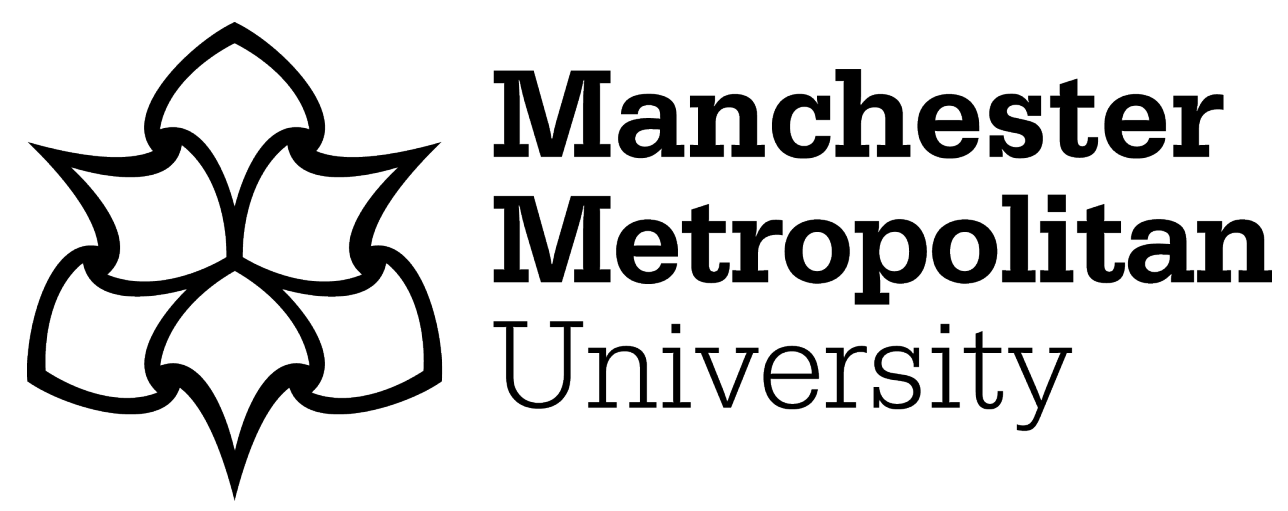

Harrison, Michaela (2022) Deleuze-inspired action research in the university: mobilising Deleuzian concepts to rethink research on the reflective writing practices of student teachers. Educational Action Research, 30 (3). pp. 395410. ISSN 0965-0792

Downloaded from: https://e-space.mmu.ac.uk/626565/

Version: Accepted Version

Publisher: Taylor \& Francis

DOI: https://doi.org/10.1080/09650792.2020.1850493

Please cite the published version 


\title{
Deleuze-inspired action research in the university: Mobilising Deleuzian concepts to rethink research on the reflective writing practices of student teachers.
}

\author{
Michaela J. Harrison
}

Faculty of Education, Manchester Metropolitan University

Brooks Building, 53 Bonsall Street, Manchester, M15 6GX.

Tel.: +441612472069

E-mail address: m.j.harrison@mmu.ac.uk

Michaela J. Harrison is senior lecturer in the Faculty of Education, Manchester Metropolitan University (England). Her research activity includes work aiming to explore the relationship between students' writing and their development as professionals. Her research and theoretical interests include; post-structuralism, feminism, new-materialism, practitioner research and writing as a form of enquiry. She received her EdD from Manchester Metropolitan University. 


\title{
Deleuze-inspired action research in the university: Mobilising Deleuzian concepts to rethink research on the reflective writing practices of student teachers.
}

\begin{abstract}
This article offers an insight into the process and potential of Deleuze-inspired action research. It draws on a classroom action research (CAR) project that critically reconceptualises practices of reflective writing in teacher education, including the widespread use of the 'professional learning journal' as a resource to facilitate reflection on practice. Students following a teacher education programme in England took part in an innovative mode of engagement with texts, including their learning journals, drawing on the Deleuzo-Guattarian notion of the text as an agent that acts outside of itself. The process was called 'implicated reading'. An example of a teaching and learning intervention, in the form of a seminar transcript, is offered as an illustration of how Deleuzian theory and philosophy can inspire and shape innovations in practice. The transcript also serves as an opportunity to reimagine the ways in which data and data analysis are conceptualised and practiced in action research (AR) projects. Data is (re)conceptualised as agentic, rather than inert or indifferent. Synthesis is privileged over analysis so that the transcript acts as a provocation to rethink the relation between theory and data, asking what is made possible when these are 'plugged into' one another to raise questions that otherwise would have remained unthought. Ultimately, the article offers a worked example of what happens when action researchers take up the challenge of working and thinking within a Deleuzian ontology that seeks to maintain the plurality and potentialities of AR in practice.
\end{abstract}

Keywords: classroom action research, Deleuze, data, analysis, reflective writing

\section{Introduction}

This paper draws on a practitioner-led classroom action research (CAR) project. At the time of the project, I taught on a large initial teacher education (ITE) programme in 
England. I adopted the classroom-based action research model (Kemmis and McTaggart 2000) to enquire into my own practice as a university-based teacher educator; an increasingly popular use of the CAR model (Noffke and Somekh 2011). At the same time, and as I grappled with the customary challenge of working through the cycles of the action research (AR) model (Drummond and Themessl-Huber 2007), I was also becoming increasingly beguiled by the philosophy of Deleuze. What transpired therefore, sometimes consciously, sometimes less so, was a Deleuze-inspired project that made 'use' of Deleuzian philosophy (Gale 2010). St. Pierre (2004) writes that engaging with Deleuzian theory has the capacity to intervene in our lives, making them different from what they were before. If this is so, it certainly has the ability to make different a model of enquiry - from project creation or idea, to praxis; from data collection to analysis; from evaluation to dissemination. This paper offers an insight into the process and potential of Deleuze-inspired AR.

I have selected two key aspects of the project to share here. This selection is purposeful in meeting the aims of this paper, that is, to offer an insight into what a Deleuze-inspired AR project might do and how it might differ from projects where nonhumanist theory and philosophy feature less prominently (Gale 2014). The first part of the paper is devoted to an example of praxis. The example takes the form of a transcript from an audio recording of a seminar in which I model a Deleuze-inspired reading activity to a group of students. The activity, named 'implicated reading' (a phrase coined by Pearce [1997] and adapted for research contexts by Alvermann [2000]), was selected as an alternative and innovative approach for engaging with written accounts of teaching practice (in this case a professional learning journal). The transcript constitutes a significant part of the paper. I appreciate this is unusual, and offer a rationale below. 
The second part of the paper is intended to offer an insight into what I learned from the AR project. However, and in keeping with the broader theoretical framing of the paper, this does not constitute an analysis in its most traditional form. Nor do I provide summaries of the project outcomes, results or findings. Instead, and taking inspiration from Jackson and Mazzei (2012), I seek to plug data and theory into one another. The purpose of this process is to think data analysis in AR differently. More specifically, it is an attempt to resist the temptation of thinking theory and practice as distinct, and rather work with the notion that one might constitute the other. In this instance, practice refers to both the practice of data analysis as well as the (teaching and learning) practice rendered accessible through the seminar transcript. The process is also to be attentive to what theory and data make possible when they are plugged into one another, what questions are raised that otherwise would have remained unthought. In order to do this I work with selected concepts drawn from Deleuze's broader philosophy of transcendental empiricism, including planes of transcendence, planes of immanence, the actual and the virtual. To provide context for both the transcript and the subsequent discussion generated through plugging in, I next outline the parameters of the project, explain the context in which it was based, and describe the implicated reading activity in more detail.

\section{Outline of the CAR project}

As part of the ITE course on which I taught, students were required to keep a professional learning journal, a common practice in teacher education $\left(\mathrm{O}^{\prime} \mathrm{C}\right.$ onnell and Dyment 2011). The learning journal constituted a compendium of written accounts, documenting troubling or intriguing events from students' experiences on school-based 
practice placements. After school-based placements had ended, students were required to share their journals with peers in university-based seminars. The journal writing, thus served as a springboard for professional learning as students engaged in a range of activities that were intended to facilitate critical reflection. This particular practice - of using journal writing as a means of professional learning - became the focus of my CAR project. My motivation, in large part, was shaped by my reading of Deleuze and Guattari (1987/2004) specifically their conceptualisation of text, explained clearly here by Alvermann (2000, 117):

...texts... are typically thought to signify meaning, albeit meaning that is contingent upon the interaction of subject (reader) and context. Less typical is Deleuze and Guattari's (1986/1980) concept of text, which is predicated on their particular decentring project - the avoidance of any orientation toward a culmination or ending point. Analysing texts from Deleuze and Guattari's perspective, it is how the texts function outside themselves that is of interest. This interest stems from the belief that texts, likes rhizomes, connect with other things (e.g., readers, other texts and contexts).

Understandably, in practice, I had found that the typical view of text dominated. As is often the case in educational settings, both students and I, relied upon the journal entries (or texts) as signifiers of both the author's experience as well as their initial interpretations and internalised responses to the events documented (Gilbert 1989). We worked on the assumption that the text had captured 'truth' and thus allowed us access to 'things that actually happened' (MacLure 2003). It was on this basis that the reflective learning activities proceeded. The task, in short, was to extrapolate from the text what had happened and then look for clues as to why. 'New learning' usually took the form of suggested alternatives to practice. The general idea on which the CAR project was based was to attempt to engage both the students and me in less typical readings of the journal entry texts. I wondered what an alternative conception of text 
might do to the professional learning that was meant to occur as a result of critically reflecting on written representations of practice. If we engaged with the texts as agents acting outside of themselves, as multiplicities of connections between people, places, things and other texts, as existing only 'through the outside and on the outside' (Deleuze and Guattari's 1987/2004,4), how would our reflective practice and professional learning be different? How would it work? What would it make possible? (St. Pierre, 2004).

In order to realise the potential of a Deleuzo-Guattarian conceptualisation of text, and in keeping with the cyclical process of AR, I planned a series of activities or forms of action (Noffke and Somekh 2011). The activities were based on the principle of implicated reading (Alvermann 2000), as a means of engaging with text in ways that rely less on hermeneutic and phenomenological practices and instead encourage a Deleuzian-style praxis of reader engagement. In this way, implicated reading necessitates a view of text as an agent that acts outside of itself and with others. As a process, this constitutes reading through texts (plural) rather than the reading of a text (singular). To this end, the reader is asked to consider texts alongside each other, remaining open to connections that in turn allow for the creation of "possible realities by producing new articulations of disparate phenomena' (Dimitriadis and Kamberelis 1997, as quoted in Alvermann 2000, 116). Once selected, the reader is encouraged to read the texts alongside each other in an attempt to consider them 'askew' (St. Pierre, 2004), focusing less on what the text means (hermeneutics) or how the subject is revealed (phenomenology) and instead ask, what do these texts do? In the context of the ITE course, this required a shift in expectation and emphasis. We had to move away from asking what the text revealed about its subjects (including, usually, its author) and context (the school) and instead, asked how the text functioned and in what ways it 
connected to the reader, to the author, to other texts, to other spaces and things. A series of questions were offered to the students to stimulate this process. For example, 'What does the journal entry 'do' to the other texts I am reading and vice versa? And, 'In what ways do I connect to the texts and they to me? Few parameters were set around the process of text selection; the only stipulation was that students should draw at least one from their learning journal. Other texts students selected included popular culture media (reflecting the cultural networks in which the students were anchored) and children's literature (reflecting the students' professional working environs). The rationale for text choices varied. Some were chosen because they were familiar or personal favourites (for example, various feature-length films), others because on reading/watching/listening to a text, students realised the potential for connections with their learning journal writing (several students selected 'fly on the wall' type documentaries or song lyrics for this reason). (For a fuller description of the implicated reading activities, see Author, 2017.)

\section{Rationale for included a full transcript}

Transcriptions or observations of seminars and lessons are commonly used data in classroom-based research. However, in reporting these projects, these data are most likely to be coded and/or categorised (for example, Dukuzumuremyi and Siklander 2018; O'Brien and Blue 2018, Virtanen, Vaaland and Ertesvåg 2019), and so do not appear in their raw form. Alternatively or additionally, smaller excerpts are extracted from the full data set and presented to support identified themes (for example, Dukuzumuremyi and Siklander 2018; Hollingsworth 1994; Martínez and Dominguez 2018). Offering a full transcription is more unusual and contentious (Collier, Moffatt and Perry, 2015) and as a result, I grappled with the idea for some time. In the end, I 
opted for a minimally edited version and therefore the transcription (or data) may well still strike the reader as peculiarly, interestingly or overly long - depending on your view. My reason for not coding, categorising, selecting extracts or further condensing the transcript is, in large part, due to the ways in which I came to understand and experience the data's wondrous qualities. The 'wonder that resides and radiates in data, or rather in the entangled relation of data-and-researcher' (MacLure 2013a, 229).

Each reading of the data, each time I have returned to it in the doing and deciding of this AR project (and its subsequent representations in papers and presentations), has resulted in a differenciated (Deleuze [1968] 2004) form of dataresearcher entanglement. In this way, the data has resisted objectification as an 'inert and indifferent mass' (MacLure 2013). It has refused to be 'marshalled as "evidence", disciplined into categories, or incorporated into higher-order concepts' (KoroLjundberg, MacLure and Ulmer 2018, 463). Rather, it has engaged me in a series of frustrating, intense and energising entanglements producing data and researcher in a series of becoming selves (Mazzei 2013). A good example is the writing of this paper: the differenciation and entanglement arising in the move from an unpublished study to a journal submission illustrating perfectly the impossibility of a straightforward reproduction or translation. Ultimately then, I have come to accept (and revel in) the post qualitative premise that data are 'much more than containable and controllable objects' (Koro-Ljungberg, Löytönen and Tesar 2018, 5) - that they too possess agency. I have tried therefore to approach these entanglements as opportunities of becoming “"with data" instead of wrestling with it [and] taming it into shape' (Malone 2018, 198).

The product of this is realised in two separate but interconnected ways in the reminder of this paper. Firstly, I have chosen to share the data with the reader in its raw 
form - as a flow of intra-action (Barad 2007). I do not interrupt it with commentary. That said, I have lightly edited the transcript, removing conversational or light-hearted snippets of dialogue. (Pragmatic considerations forced this decision to edit. The longer than usual transcript resulted in a longer than usual paper for publication. To reduce its length, I deleted any sentences and clauses I judged as expendable in the endeavour of meeting the paper's aims.) Secondly, I have purposely avoided analysing the data by organising it into categories. I have, instead, privileged synthesis over analysis (Clarke and Parsons 2013) in an attempt to 'mobilise data as a resource for thought' (MacLure 2018,xviii). My method is to plug theory and data into one another and see what happens (Jackson and Mazzei 2012).

Finally, the transcript also serves to exemplify the potential in Deleuzian philosophy for creating new forms of teaching and learning practice or, in this case, more aptly, praxis. As Hanley and Torrance (2011) note, Deleuzian concepts open up sites for productive forces of innovation in practice. The transcript offers an insight into how these productive forces might merge to produce new planes of intensities and becomings (Roy 2003) in some common teacher educator practices.

\section{Contextualizing the transcript}

Data out of context can be difficult to engage with and understand. This is compounded when that context is the complex milieu of a teaching and learning event. As such, I offer a brief contextualisation.

The transcript relays the opening 20 minutes of a seminar class in which I model implicated reading. In doing so, I attempted to imitate the process from the students' perspective. I read across two texts. The first was a learning journal entry I had written 
several years earlier when I worked as a classroom teacher. I had titled the journal entry 'The Shoe-trainer Hybrid'. The writing recounted an incident in my first year of teaching where I had struggled to identify the purpose and merit of my employer's school uniform policy and, as a result, had made less than enthusiastic attempts to implement it. The uniform policy forbade 'shoe-trainers'. According to colleagues, 'shoe-trainers' were trainers (unpermitted school footwear) purposely designed by manufacturers to look like shoes (permitted school footwear), and, as a result, were not authorised school uniform. The journal entry recounted incredulity on my part (I had failed to see the problem with shoe-trainers) as well as an interaction with a small group of pupils where, with little conviction, and some flippancy, I attempted to explain that their footwear was not permitted. I chose to use this particular journal entry to model the implicated read because of its availability and familiarity. I had already used it several times as a teaching resource. The second text was a scene from the film Star Trek: First Contact ${ }^{2}$ (1996) (a personal favourite with familial associations. I have watched the film several times with my dad. We are both fans). The scene depicted a battle between Starfleet personnel and Borg ${ }^{3}$. As per my usual practice, the content of the seminar was pre-planned and students had been given the opportunity to familiarise

1 'Trainers' is a commonly used term in the UK. It refers to a sports or casual shoe.

${ }^{2}$ Star Trek: First Contact is a feature film from the Star Trek Franchise. It recounts the (science)fictional exploits of 'Starfleet', a deep space defence contingent maintained by the Federation. The Federation is guided by principles of peaceful exploration and intellectual curiosity.

${ }^{3}$ Borg are an interlinked malevolent alien race of cyborgs that operative as a collective with the purpose of assimilating all other races. 
themselves with both texts prior to the seminar.

All student participants gave written consent for their in-class responses to be included in publications and papers. Institutional ethical approval for the AR project was sought and granted.

\section{Seminar transcript}

Me: ... implicated reading... the process is about you making connections between one text and another and the result of that process is that you understand text differently, as a result of looking at it in this different way. So I had a go at it myself with Star Trek. So we're going to watch the clip of Star Trek and then I'm going to take you through the process, does that make sense?

[We watch the film clip.]

Me: OK, does anyone want to ask any questions about the film? Like who anyone was, or what was going on?

Student C: I have loads of questions. Who are those alien people?

Me: Right those are the baddies, they are Borg, so what they want is...

Student A: their knowledge?

Me: Well, kind of, yeah, everything about them ... they are a collective and what this means is that they have one mind. Everything about them is the same... and the reason they are such a powerful race is they assimilate other races, erm, other worlds. So you've got Earth... and it's full of human beings and humans have their own special characteristics, erm... they have personalities, intelligence, abilities and lots of other 
good stuff and Borg... what they do is, they invade and then they assimilate all of those good people, they make them into Borg. Does that make sense? ...once you're assimilated you are connected to what is called the hive mind and it basically takes away your free will.

Okay? Right, well my intention was to use this part of the film, in particular the Borg, to help me to think about the story of The Shoe-trainer Hybrid differently. Do you remember The Shoe-trainer Hybrid story?

Student A: Yeah.

Me: Thank you. So, I find Borg fascinating. So, what do they make me think of? Well, obviously, they make me think of fancy, philosophical questions about identity. What makes a person, a person? These are some things that I was thinking. Remember that those kids were wearing shoe-trainer hybrids and I sort of laughed it off and said next time... in future, ask your mum and dad to get you something that's more like a shoe and they laughed and said we're wearing them because they are shoe-trainers and I knew what I should have done is say, 'I have noticed that you are wearing a shoetrainer hybrid and that's against school policy,' but I didn't. Well... I started to think about the shoe-trainer ... remember when Borg were saying resistance is futile?

...there is no point in resisting assimilation, it's going to happen to you; you're going to be got by Borg: the uniformity, the conformity of school; you are going to be got by it, there is no point resisting. Now, what these two kids [the children in The Shoe-trainer Hybrid] are doing; they are being a bit resistant. They are being a bit clever and they know exactly what they are doing and I like that idea and that's maybe why I keep telling this story and that's probably why I was so reluctant to do anything about it 
because resistance... that's a nice little concept there in an educational setting, is it not? Resisting... what film is it? There's a film and in it they call it 'The Man'. What film is it? Erm... Jack Black's in it.

Student D: School of Rock.

Me: School of Rock. Put your hand up if you've seen School of Rock. [Lots of hands go up.] It's about resisting 'The Man'. Yeah? And the man is basically a metaphor for the person who tells you what you should be doing with your life - the way that you act, the things that you say... that is 'The Man' and what they are doing is resisting and I like it because small, little acts of resistance, that's quite a nice thing to be part of, like the secrecy of having these shoe-trainer hybrids on and thinking 'yeah, I'm sticking it to The Man'. So I like it, and I kind of like the part that I played in allowing them to do that because if you suppress all those little acts of resistance then... I become 'The Man' and I don't want to be 'The Man'. There is something else that I thought of....

Student E: What happened to the boys? Did they, erm, get new shoes or...

Me: Can't remember... it was quite a while ago.

Student F: I just wondered, like, did they get new shoes or...

Me: Erm, let me think. Well, it was one of those things that at the time it was big news... and then the following September they go up to another class and I've got no idea what shoes they wear... okay but... I'm thinking about these kids and I'm thinking about it from these kids' position and they've kind of got this little shared secret... the point is, resisting something and having that little group... you are somehow separate to the teachers and they're the big guys, they're trying to rule you and you do those little things that let you win, even if it's for only a moment in the morning when you put your 
shoe-trainers on, you're winning and that's quite an empowering thing, but in this kind of odd way, I take that away from them because I want to be as cool as they are. I want to be in on the secret - does that make sense?

Student G: Did you get some trainer hybrids? [Students laugh.]

Me: Ha, ha, no. In some kind of way, I stop it from being this cool little secret because I want to be in on the secret because I'm also young and cool and I just wonder if there's a little bit of that there. For them to be empowered by resistance, maybe I needed to be 'The Man'. Maybe the bigger thing for me to do would have been; 'I know about those shoe-trainer hybrids; it's not on.' Maybe they wouldn't have worn them anymore, but the point is I would have given the opportunity to resist me, to be secretive about something and that's exciting. I've never thought about that before. Maybe, I tell the story because I think it makes me look good. Maybe, on reflection it doesn't make me look good at all. All possibilities, some of which I have never thought about before, but thanks to Borg, I now have.

\section{This is not data analysis}

There have been many variations of AR since Lewin coined the phrase in the 1940s (Noffke and Somekh 2011). Despite this divergence, the ubiquity of AR as a series of stages or processes persists (Drummond and Themessl-Huber 2007) and within these stages, cycles, spirals or phases of AR, we can note another commonality: analysis (McNiff 2016). Unsurprisingly, there are as many ways of envisioning and executing this familiar aspect of AR practice, as there are forms and types of AR, a pluralism augmented by the multi-paradigmatic character of educational AR (Katsarou, 2017). That said, I am keen to avoid familiar and futile tropes of paradigm wars by engaging in 
‘tiresome epistemological contests' (Lather 2007, cited in Mazzei and McCoy 2010) and so I do not intend to compare and contrast approaches. Rather, and following the lead of Mazzei and McCoy (2010), I choose instead to defer to examples in that I hope the remainder of this paper might exemplify a response to the question; what might analysis do in a Deleuze-inspired CAR project?

Firstly, it is important to reiterate that I have purposefully chosen to privilege synthesis over analysis (Clarke and Parson 2013) and so look for interconnections rather than separations. If synthesis is the process of connection then it is distinctly Deleuzian. Assemblages, rhizomes, multiplicities, exteriority, becoming... they all emphasise Deleuze's ontology, that 'life is connection and relation' (Colebrook 2005, 5). In this context, there is nothing else to do but accept that Deleuzian AR 'cannot be captured, organised, systematised and transformed into public knowledge' (Amorium and Ryan 2005, 583). Rather, as Foucault states, the Deleuzian art of living (and therefore research) requires a preference for 'difference over uniformity, flows over unities, mobile arrangements over systems' ([1972] 2004, xv). Given this, there seems a sense of incompatibility between a process of analysis that seeks to separate data into codes or categories and Deleuzian philosophy in general. To take such an approach would, in the words of Mazzei and McCoy, be 'simply re-inscribing the old methodology with [a] new language' $(2010,504)$. This seems at least a wasted opportunity. Rather the challenge is in the experiment (Torrance 2017) - how might I bring Deleuzian philosophy to bear as I enact qualitative synthesis? There are various approaches; rhizoanalysis (Alvermann 2000), nomad science (Cole 2013), more-than-human visual analysis (Lorimer 2013). None are analytical strategies in the conventional sense, but might usefully be described as mappings in the Deleuzian sense. For the purposes of this paper, I take the lead from Jackson and Mazzei (2012) and opt to think data 
synthesis with the process of plugging in. Jackson and Mazzei explain this as constituting three manoeuvres. In what follows, I attempt to remain faithful to manoeuvres one and two, as detailed below. The third and final manoeuvre involves working with the same data chunks repeatedly. I have not attempted this manoeuvre because of the obvious conflict between this and my decision to present a (nearly) full data set in the first half of this paper.

Manoeuvres for plugging in:

1 putting philosophical concepts to work via disputing the theory/practice binary by decentring each and instead showing how they constitute or make one another,

2 being deliberate and transparent in what analytical questions are made possible by a specific theoretical concept... and how the questions that are used to think with emerged in the middle of plugging in... (Jackson and Mazzei 2012, 5)

\section{What happens when we plug the theory and the data into one another?}

\section{Plugging in Deleuzian philosophy - transcendental empiricism}

Patton rather delightfully describes the work of Deleuze (and particularly his collaborations with Felix Guattari) as one of this century's most 'audacious experiment[s] in thought' $(1997,1)$. This experiment, Deleuze and Guattari argue, is a serious and necessary endeavour. They warn that the less we take thought seriously, the less able we are to think otherwise and the more likely we are to live as functionaries of the state ([1987] 2004, 415). Indeed, it seems thought is the central component of Deleuzian philosophy. This is what philosophy is (or should be) and what it does (or should do); it should create new modes or styles of thinking (Colman 2010). The history of philosophy, Deleuze and Guattari claim (1994), can be understood as a sort of 
grandiose construction project, of enormous scale and complexity, where western philosophers have, over centuries, worked to secure the foundations for thinking via the meticulous construction of planes of transcendence. Planes of transcendence, they argue, are philosophy's creation - the normative and universal building blocks of our world and life as we think and understand it. They are superseding and subordinating forms (Jackson and Mazzei 2012), separate and distinct from the human subject, and so identifiable and knowable. But the forms are creations: they are illusions; philosophy's illusions; transcendental illusions (Boundas 1997). Yet such is their pervasiveness that they have ensured our world, or at least our image of the world has been understood, represented and encountered in their likeness. We think with/in/on planes of transcendence; relying on these discrete manifold forms of the enlightenment (truth, god, science and culture) to extort and extrapolate an exterior world from a rational human subject (the interior mind that makes sense of them). This is an image of the world from which we can readily (and reassuringly) compile taxonomies and typologies, or, in other words, structures and systems to explain our reality (Colman 2010). Deleuze and Guattari define this world created for and by us as the world of 'representation'. In limiting the nature of thought, the potential for something other to occur is similarly limited. In this explanation of the world, variation, learning and creativity are constrained to the extent that they can only be experienced against the concept of sameness: they are different only in the sense of 'difference-from-the-same' (Stagoll 2010). Philosophy, in essence, is not thinking anything anew, but rather representing the same image of the world over and over again. Deleuze's challenge to our exclusive preoccupations with transcendence is to recognise, accept and think the alternative; of life as it is, rather than what we need it to be. This is Deleuze's philosophy - transcendental empiricism. It requires that we accept life as nothing more 
or less than flows of experience, of becoming and interaction and that there is nothing that transcends this experience that can enclose or explain it; not subject, object, culture, truth or god (Colebrook 2002).

Transcendental empiricism is Deleuze's philosophy: it is also method (Boundas 1997); a way to rethink the world and its various components. Roy (2003), writing about Deleuze and school curriculum, offers an example of transcendental empiricism as method well suited to my purposes here, as a means of understanding how theory and practice constitute one another in the teaching and learning events that unfold in the implicated read. If we are to resist the temptation to think teaching and learning through planes of transcendence (for example looking for categories of practice; assessment, behaviour management, subject knowledge etc.), Roy suggests that we purposefully divert our attention and instead look to the "the passages and transformations, at the outer edges of phenomena' $(2003,21)$. This suggestion needs a little unpicking... the evoking of phenomena grounds the practice Roy advocates in empiricism, so the occurrence or event remains key - it is the site or stimulus for thinking. However, our focus, our gaze needs diverting - from the essence of the thing and instead towards the outer edges, the passages and transformations. This process and its purpose become clearer if you consider how the practice of transcendental empiricism works from the premise of life as an immanent flow of experience. Semetsky (2010) describes Deleuze's concept of experience as multidimensional, inclusive, qualitative, yet subjectless (because for Deleuze we are not a singular entity, rather we are made up of relations). It is inclusive of flows of becoming and interactions (Coleman 2002) or 'passages and transformations'. The passages are the flows and connections of interacting bodies, places, artefacts and affects that in turn mutate and generate difference or transformations in the experience itself. It is towards these we should 
direct our attention, our thinking. They bear the promise of reconceptualisation, moving us beyond representationalist ways of thinking and knowing through practice-based categories. We are not seeking the essence of the thing (there never was one).

I ask, does re-reading The Shoe-trainer Hybrid against Star Trek: First Contact create a kind of diversion; a shudder or stammer in the course of business as usual? Is it this improbable distraction ('what has Star Trek got to do with teaching?') that compels us to gaze outwards and so look beyond the essentialised categories of teaching and learning which typify educational discourses? How easily we might have entered into an analysis of practice categories, of behaviour management or notions of professionalism. Instead, we explore the concepts of resistance and futility, reframing the pupils' minor misdemeanours as productive sites for communal empowerment where shared secrets and codes disturb power relations and positionings in a way that we might, on reflection, wish to preserve. In this manner, I could argue that the outer edges of phenomena, revealed by the implicated reading have produced new ways of thinking with the encounters and events, the learning journal describes.

There is more to contemplate. Thus far, I have considered the implicated read as an actual event that encouraged actual thoughts in relation to actual things. To end the plugging-in here would be to limit it to the realms of the (actual) real and the possible; according to Boundas (1997), another symptom of our exclusive preoccupation with philosophy's transcendental illusion. Instead, and as Williams makes clear, any ‘full explanation of an event [in Deleuze's terms] must involve a consideration of the virtual and of the actual and, more importantly, of the ways in which actual events touch on virtual events $(2008,9)$. To this end, I draw on Masny's exemplification of transcendental empiricism as a conceptualisation of experience. The analogy is 
particularly useful as it brings together and develops the various components of Deleuzian philosophy that I have attempted to work with so far. Imagine you are walking along a corridor at work and smell coffee.

The reading of the smell of coffee has disrupted. What could happen next? The clock on the wall says it is 4 o'clock: a visual and printed reading. There is a rhizomatic rupture [my emphasis]; whatever has been going on has been disrupted/deterritorialized. The rupture brings on the virtual thought of a break, a going home or potentially the thought of a next vacation. Where the smell of coffee could lead is unpredictable. (Masny, 2013:341)

Here we can see experience as it is conceptualised in Deleuzian terms, as multidimensional and inclusive (Semetsky, 2010). These qualities are borne out through the recognition of actual-virtual interaction or, in other words, the ways in which these two interrelated realms of reality condition our engagement with or in the world (in this instance, walking along a corridor at work). Plugging the data and theory into one another I ask what happens when the implicated reading is thought of in these terms as a rhizomatic rupture that brings on the virtual (Masny 2013)? This is an opening question; it leads to others... What might I identify as being disrupted here? How is the virtual brought forth and actualised through action, memory or perception (May 2005)? What is returned from the virtual to the actual?

In pondering these questions, new ways of thinking with the data emerge - ways that highlight the dynamism in the actual-virtual relation manifest in the interaction between the students and me as I suggest or advocate the potential of implicated reading and they respond. Three interactions provoke a response. Two are similar and so I will consider these together first: they pertain to 'outcomes' (very much in the realm of the actual for student teachers). Student E asks: What happened to the boys? Did they, erm, get new shoes or... Student F remarks: I just wondered, like, did they get new shoes or... 
These questions are affirmations of the actual - they are attempts to ascertain 'what actually happened'. Such affirmations are potentially resistant, in that they resist the process of return by which the virtual might be actualised through memory and action. To explain, in the process of the implicated read, the actuality of the event the journal entry relays, the realm of actual identifiable things (May 2005); trainers, shoes, actions, behaviours, rules, responses, is ruptured. The rupture calls forth the background of contingent potentialities - the virtual thoughts of ... (Masny 2013). They were always there, these virtual elements but the implicated read, the rupture forces them into consciousness. This is a plane of immanence. It is a reality of contingency, potentiality and difference, which can be, in different measures for different individuals, liberating and frightening. To accept and think in the realms of an actual-virtual reality is to lose the sense of absoluteness in a situation or event and it can be an uncomfortable and often disturbing experience. I ask, is this what drives the students' interventions here? Are affirmations of the actual attempts by the students to quell the unease or disturbance; to refocus our attention on 'what actually happened in the end? As Drummond and Themessl-Huber explain; 'what returns from the virtual in the process of actualization is determined by how we relate to and what we affirm in the actual' (2007, 435).

The third intervention (Student G: Did you get some trainer hybrids?) raises similar questions, but as it carries with it the purpose of affecting humour, I shall consider it separately. I wonder how Student G's interjection might work as a reaffirmation of the actual but with the added effect of affecting the temporal framework which holds the implicated read in place (and possibly therefore adding to the efficacy of the tactic). Laughter is located very much in the present; it is the here and now, the real, the actual. As a result of sharing laughter together the students and I 
can return to the comfort of a single, knowable and familiar realm of reality - the actual. It is a referral that has the potential to relocate us as subjects, at once and together, in the same time, living an experience that can be easily and reassuringly divided into cause and effect: You joke, we laugh; the actual to the actual.

Finally, I return to the overarching question posed at the beginning of this section. I can now ask the question in retrospect... 'is this what happens when we plug the theory and the data into one another?' In response, I refer back to Jackson and Mazzei's manoeuvres for plugging in as a reminder that the analytical questions used to think the data with the theory were only 'made possible by [the] specific theoretical concept[s]' (Jackson and Mazzei 2012, 5) of transcendental empiricism. Should I have had the space here to return to the data (Jackson and Mazzei's third manoeuvre) with different concepts, 'what happens when' would be markedly different. This is partly why plugging in differs from more commonplace approaches to data analysis (for example interpretation and categorisation). Such approaches assume data are merely expressions or representations of an underlying meaning, compelling researchers to 'overcode' it (Colebrook, 2002) with claims we have discovered what was lying underneath. I suggest what I have exemplified here is a rejection of this compulsion, via a subtle but important distinction. The synthesis is made possible because particular concepts provoked particular analytical questions. The purpose and outcome of this process is not the discovery of meaning, rather the creation of new styles of perception (Colebrook, 2002).

\section{Ending in the middle: acknowledging the challenges}

If Deleuzian theory is a philosophy of use (Gale 2010), this paper can be read as an attempt to put that use to work in CAR. More specifically, I have focused on the ways 
in which Deleuze might inspire alternative conceptualisations of and entanglements and becomings with praxis, data and analysis (or synthesis); exemplifying (via the extended transcript) how Deleuzian theory and philosophy can inspire and shape innovations in practice and (through plugging in) how data and theory can be synthesised. In doing so, I have challenged conventional practices in AR projects, particularly in relation to how the action of the research is reported and evaluated. I suggest that AR is not, or at least, does not have to be, grounded in humanistic practices of phenomenology and hermeneutics. Instead, I agree with scholars who have argued that despite their seemingly contradictory appearances, Deleuze and AR share many of the same proclivities and can be complementary and productive partners in our research endeavours (Amorium and Ryan 2005; Drummond and Themessl-Huber 2007; Kane, 2015).

That said, regardless of their mutual benefit, the challenges of Deleuze-inspired $\mathrm{AR}$ are plentiful, and I have found that in remaining cognisant and therefore vigilant in addressing some, I have failed in respect of others. I have been diligent (I hope) in avoiding the pitfall of simply re-describing 'business as usual' AR using a Deleuziandialect. I have instead attempted to rethink the very foundations of data and analysis in AR. The implications of this have been a marked shift in emphasis. The study has not yielded (or reported) results, outcomes or findings in the same way as more traditional AR projects might. Instead, what has materialised is more of an experiment in 'what happens when?' What happens when we plug theory into data? What happens when we rethink what data is and can do? What happens in the entanglement of AR and Deleuzian philosophy? In this way, what has become clearer are the potentialities of AR rethought with Deleuze. 
What has been far more difficult, impossible even, is containing and limiting the effect of Deleuzian philosophy. The purpose of this paper was to illustrate what a Deleuze-inspired AR project might do, but on reflection, what might have been more appropriate was to illustrate how Deleuze-inspired AR behaves; how it acts, what is the nature of its becoming? For example, despite my best efforts to define the parameters of this paper, Deleuzian AR (perhaps unsurprisingly) played true to form and continuously resisted my attempts to control or discipline it into an organised and refined account of data and synthesis. The trajectory of the paper was often diverted as theory spilled out, over and through my attempts to maintain and develop a central argument to answer the question of 'what might happen when?'. In Deleuze-inspired AR, theory refuses to take its place in the theory/practice binary, but lives through, within and in praxis. Perhaps then, confining and defining the effect of Deleuze on... was always going to be an impossible task, premised as it is on the existence of intelligible bounded and boundaried systems of thought, action, theory and practice. Instead, what emerges are simply fragments of the rhizome, the results of a series of agential cuts (Barad 2007) into a Deleuze-inspired AR becoming.

\section{References}

Alvermann, Donna. E. 2000. "Researching libraries, literacies, and lives: A rhizoanalysis." In Working the Ruins: Feminist poststructural theory and methods in education, edited by Elizabeth A. St. Pierre, and Wanda S. Pillow, 114-129. New York, NY: Routledge.

Amorim, Antonio Carlos, and Charly Ryan. 2005. "Deleuze, Action Research and Rhizomatic Growth.” Educational Action Research 13 (4): 581- 594. doi:10.1080/09650790500200306.

Author, Author. 2017. "Implicated reading: a method for reflecting on practice." Reflective Practice 18 (3): 312-325. doi: 10.1080/14623943.2016.1275535

Barad, Karen. 2007. Meeting the Universe Halfway: Quantum Physics and the Entanglement of Matter and Meaning. London: Duke University Press. 
Boundas, Constantin. V. 1997. "Deleuze-Bergson: an Ontology of the Virtual." In Deleuze: A Critical Reader, edited by Paul Patton, 81-106. Oxford: Blackwell Publishers Ltd.

Clarke, Bryan, and Jim Parsons. 2013. "Becoming Rhizome Researchers." Reconceptualizing Educational Research Methodology 4 (1): 35-43. doi: https://doi.org/10.7577/rerm.685.

Cole, David. R. 2013. "Lost in Data Space: Using Nomadic Analysis to Perform Social Science." In Deleuze and Research Methodologies, edited by Rebecca Coleman and Jessica Ringrose, 219-237. Edinburgh: Edinburgh University Press.

Colebrook, Claire. 2002. Gilles Deleuze. London: Routledge.

Collier, Diane. R., Lyndsay Moffatt, and Mia Perry. 2015. "Talking, wrestling, and recycling: an investigation of three analytic approaches to qualitative date in education research." Qualitative Research 15 (3): 389-404. doi:10.1177/1468794114538896.

Colman, Felicity. J. 2010. "Rhizome.” In The Deleuze Dictionary. Revised edition, edited by Adrian Parr, 232-235. Edinburgh: Edinburgh University Press.

Deleuze, Gilles. (1968) 2004. Difference and Repetition. Reprint, London UK: Continuum International Publishing Group.

Deleuze, Gilles, and Félix Guattari. (1987) 2004. A Thousand Plateaus: Capitalism and schizophrenia. Reprint, London: Continuum International Publishing Group.

Deleuze, Gilles, and Félix Guattari. 1994. What Is Philosophy? London: Verso.

Drummond, John. S., and Markus Themessl-Huber. 2007. "The Cyclical Process of Action Research: The contribution of Gilles Deleuze." Action Research 5 (4): 430-448. doi: $10.1177 / 1476750307077317$.

Dukuzumuremyi, Salvador, and Pirkko Siklander. 2018. "Interactions between pupils and their teacher in collaborative and technology-enhanced learning settings in the inclusive classroom." Teaching and Teacher Education 76: 165-174.

https://doi.org/10.1016/j.tate.2018.08.010.

Foucault, Michel. (1972) 2004. "Preface." In Anti-Oedipus: Capitalism and Schizophrenia. Gilles Deleuze, and Félix Guattari, xiii-xvi. London: Continuum International Publishing Group.

Gale, Ken. 2010. "Putting Deleuze to Work." Paper presented at The Summer Institute in Qualitative Research, Manchester Metropolitan University. Manchester, July 19-23.

Gale, Ken. 2014. "Action research and the assemblage: engaging Deleuzian pedagogy and inquiry beyond the constraints of the individual and the group in education 
settings." International Journal of Qualitative Studies in Education 27 (5): 667-681. doi: 10.1080/09518398.2013.805447.

Gilbert, Pam. 1989. Writing, schooling, and deconstruction. London: Routledge.

Hanley, Una, and Harry Torrance. 2011. "Curriculum Innovation: Difference and Resemblance." Mathematics Teacher Education and Development 13 (2): 67-84. https://mted.merga.net.au/index.php/mted/article/view/42/155

Hollingsworth, Sandra. 1994. "Feminist pedagogy in the research class: an example of teacher research." Educational Action Research 2 (1): 49-70. doi: $\underline{10.1080 / 09650799400200008 .}$.

Jackson, Alecia. Y. and Lisa. A. Mazzei. 2012. Thinking with Theory in Qualitative Research: Viewing data across multiple perspectives. Oxon: Routledge.

Kane, Eva. 2015. "What If? As If", an approach to action research practice: becomingdifferent in school-age childcare." Educational Action Research 23 (3): 350-365. doi: $\underline{10.1080 / 09650792.2015 .1009926 .}$.

Katsarou, Eleni. 2017. "The multi-paradigmatic character of contemporary educational action research: a promising perspective or an underlying threat? Educational Action Research 25 (5): 673-686. doi:10.1080/09650792.2016.1241184.

Kemmis, Stephen, and Robin McTaggart. 2000. "Participatory Action Research." In The SAGE Handbook of Qualitative Research. $2^{\text {nd }}$ ed., edited by Norman K. Denzin, and Yvonna S. Lincoln, 567-605. Thousand Oaks, CA: Sage Publications

Koro-Ljundberg, Mirka, MacLure Maggie and Jasmine Ulmer. 2018. “D...a...t...a..., Data++, Data, and Some Problematics." In The SAGE Handbook of Qualitative Research. $5^{\text {th }}$ ed., edited by Norman K. Denzin, and Yvonna S. Lincoln, 462-484. Thousand Oaks, CA: Sage Publications

Koro-Ljungberg, Mirka, Teija Löytönen, and Marek Tesar. 2018. "Introduction: Multiplicities of Data Encounters." In Disrupting Data in Qualitative Inquiry. Entanglements with the Post-Critical and Post-Anthropocentric, edited by Mirka KoroLjungberg, Teija Löytönen, and Marek Tesar, 1-9. New York, NY: Peter Lang Publishing, Inc.

Lorimer, Jamie. 2013. "More-Than-Human Visual Analysis: Witnessing and Evoking Affect in Human-Nonhuman Interactions.” Deleuze and Research Methodologies, edited by Rebecca Coleman, and Jessica Ringrose, 61-78. Edinburgh: Edinburgh University Press.

MacLure, Maggie. 2013. "Researching without representation? Language and materiality in post-qualitative methodology." International Journal of Qualitative Studies in Education 26 (6): 658- 667. doi: 10.1080/09518398.2013.788755. 
MacLure, Maggie. 2013a. "The Wonder of Data." Cultural Studies $<=>$ Critical Methodologies 13 (4): 228-232. doi: 10.1177/1532708613487863.

MacLure, Maggie. 2018. "Foreword." In Disrupting Data in Qualitative Inquiry. Entanglements with the Post-Critical and Post-Anthropocentric, edited by Mirka KoroLjungberg, Teija Löytönen, and Marek Tesar, xvii-xviii. New York, NY: Peter Lang Publishing, Inc.

Masny, Diana. 2013. "Rhizoanalytic Pathways in Qualitative Research." Qualitative Inquiry 19 (5), 339-348. doi:10.1177/1077800413479559.

May, Todd. 2005. Gilles Deleuze: An introduction. Cambridge: Cambridge University Press.

McNiff, Jean. 2016. You and Your Action Research Project. $4^{\text {th }}$ ed. Oxen: Routledge.

Malone, Karen. 2018. "Grappling with Data." In Disrupting Data in Qualitative Inquiry. Entanglements with the Post-Critical and Post-Anthropocentric, edited by Mirka Koro-Ljungberg, Teija Löytönen, and Marek Tesar, 197-210. New York, NY: Peter Lang Publishing, Inc.

Martínez, José Manuel, and Higinio Dominguez. 2018. "Navigating mathematics and language tensions in language immersion classrooms." Teaching and Teacher Education 75: 1-9. https://doi.org/10.1016/j.tate.2018.05.013.

Mazzei, Lisa. A. 2013 "Posthuman Enactments of Vibrant Data." Paper presented at The Summer Institute in Qualitative Research, Manchester Metropolitan University. Manchester, July 22- 26.

Mazzei, Lisa. A., and Kate McCoy. 2010. "Thinking with Deleuze in qualitative research.” International Journal of Qualitative Studies in Education 23 (5): 503-509. doi: $10.1080 / 09518398.2010 .500634$.

Noffke, Susan, and Bridget Somekh. 2011. “Action Research.” In Theory and Methods in Social Research. $2^{\text {nd }}$ ed., edited by Bridget Somekh, and Cathy Lewin, 94- 101. London: Sage Publications Limited.

O'Connell, Timothy. S., and Janet. E. Dyment. 2011. "The case of reflective journals: is the jury still out?" Reflective Practice, 12, 47-59. doi: 10.1080/14623943.2011.541093.

O’Brien, Mia, and Levon Blue. 2018. "Towards a positive pedagogy: designing pedagogical practices that facilitate positivity within the classroom." Educational Action Research 23 (3): 365-384. doi: 10.1080/09650792.2017.1339620.

Patton, Paul. 1997. "Introduction.” In Deleuze: A Critical Reader, edited by Paul Patton, 1-17. Oxford: Blackwell Publishers Ltd.

Pearce, Lynne. 1997. Feminism and the Politics of Reading. London: Arnold. 
Roy, Kaustuv. 2003. Teachers in Nomadic Spaces: Deleuze and Curriculum. New York: Peter Lang Publishing, Inc.

St. Pierre, Elizabeth Adams. 2004. "Deleuzian Concepts for Education: The subject undone." Educational Philosophy and Theory 36 (3): 283-296. doi:10.1111/j.1469$\underline{5812.2004 .00068 . x}$.

St. Pierre, Elizabeth Adams. 2013. "The Appearance of Data." Cultural Studies $<=>$ Critical Methodologies 13 (4): 223- 227. doi:10.1177/1532708613487862.

Stagoll, Cliff. 2010. "Becoming." In The Deleuze Dictionary. Revised edition, edited by Adrian Parr, 25-27. Edinburgh: Edinburgh University Press.

Semetsky, Inna. 2010. “Experience.” In The Deleuze Dictionary. Revised edition, edited by Adrian Parr, 91-93. Edinburgh: Edinburgh University Press.

Star Trek: First Contact. DVD. 1996. Directed by J. Frakes. California: Paramount Home Entertainment.

Torrance, Harry. 2017. "Experimenting with Qualitative Inquiry.” Qualitative Inquiry 23(1): 69-76. doi:10.1177/1077800416649201.

Williams, James. 2008. Gilles Deleuze's Difference and Repetition: A Critical Introduction and Guide. Delhi: Motilal Banarsidass Publishers Private Limited.

Virtanen, Tuomo Erkki., Grete Sørensen Vaaland, and Sigrun Karin Ertesvåg. 2019. "Associations between observed patterns of classroom interactions and teacher wellbeing in lower secondary school." Teaching and Teacher Education 77: 240-252. https://doi.org/10.1016/j.tate.2018.10.013. 
